\title{
PENYEDIAAN DAN PENCIRIAN HIDROGEL BERASASKAN KANJI/AKRILAMIDA DARIPADA UBI Stemona curtisii
}

\author{
(Preparation and Characterization of Starch/Acrylamide-Based Hydrogel \\ from Stemona curtissi Tuber)
}

\author{
Lim Wun Pin, Airul Ashri, Muntaz Abu Bakar, Wan Yaacob Wan Ahmad, Mohd Azwani Shah Mat Lazim* \\ Pusat Pengajian Sains Kimia \& Teknologi Makanan, \\ Fakulti Sains dan Teknologi \\ Universiti Kebangsaan Malaysia, 43600 UKM Bangi, Selangor, Malaysia \\ *Corresponding author: azwanlazim@ukm.edu.my
}

Received: 13 July 2015; Accepted: 11 January 2016

\begin{abstract}
Abstrak
Dalam kajian ini, hidrogel berasaskan kanji daripada ubi Stemona curtisii disintesis melalui kaedah pempolimeran radikal bebas menggunakan penyinaran gelombang mikro. Dalam kajian ini terdapat 3 jenis hidrogel dengan nisbah kanji kepada akrilamida yang berbeza dianalisis iaitu 1:3, 1:4 dan 5:3. Berdasarkan kepada ujian pembengkakan, hidrogel 1:3 mempunyai peratus pembengkakan paling tinggi dan ini dibuktikan dengan keputusan yang diperolehi daripada Mikroskop Pengimbas Elektron (SEM) di mana mikrograf SEM mempamerkan saiz liang pada hidrogel 1:3 adalah yang paling besar. Analisis menggunakan Spektroskopi Inframerah Transformasi Fourier-Jumlah Pantulan Teratenuat (ATR-FTIR) menunjukkan kehadiran puncak pada $1112 \mathrm{~cm}^{-1}, 1152 \mathrm{~cm}^{-1}$ dan $1150 \mathrm{~cm}^{-1}$ pada hidrogel 1:4, 1:3 dan 5:3 masing-masing yang menandakan pembentukan ikatan C-O$\mathrm{C}$ hasil daripada proses pempolimeran taut silang. Analisis menggunakan Difraktometer Sinar-X (XRD) pula menunjukkan bahawa ketiga - tiga jenis hidrogel adalah amorfus. Kalorimeter Pengimbas Kebedaan (DSC) pula memberikan maklumat bahawa semua bahan yang digunakan untuk sintesis hidrogel adalah pada tahap kebolehcampuran yang baik dan hidrogel 1:4 menunjukkan suhu peralihan kaca $\left(\mathrm{T}_{\mathrm{g}}\right)$ yang paling tinggi. Daripada termogram TGA/DTG pula, hidrogel 5:3 didapati lebih stabil terhadap haba berbanding hidrogel yang lain. Keputusan ujian Tegangan menggunakan Mesin Ujian Universal (UTM) telah mendapati bahawa hidrogel berasaskan kanji Ubi Stemona curtisii yang disintesis mempunyai potensi untuk diaplikasikan sebagai pembalut luka. Dalam ujian ini, hidrogel 1:4 yang mempunyai kandungan kanji yang paling rendah telah menunjukkan nilai modulus elastik Young yang paling tinggi.
\end{abstract}

Kata kunci: Stemona curtisii, hidrogel, pempolimeran radikal bebas, gelombang mikro

\section{Abstract}

In this study, hydrogel based on starch of Stemona curtisii was synthesized via free radical polymerization method by using microwave irradiation. In this study, there were three type of hydrogels formulated with different type of starch to acryamide been anaylyzed which were 1:3, 1:4 and 5:3. Based on swelling test, hydrogel with 1:3 was reported to have the highest swelling percentage where this is prove by Scanning Electron Microscope result. The SEM micrograph shows that hydrogel 1:3 have the largest pores size compare to the other two types of hydrogels. The polymerization reaction has been proven to occur successfully based on the analysis using Attenuated Total Reflection-Fourier Transform Infrared Spectroscopy (ATR-FTIR). Cross-linking polymerization process was determine by the present of peak at $1112 \mathrm{~cm}^{-1}, 1152 \mathrm{~cm}^{-1}$ and $1150 \mathrm{~cm}^{-1}$ in hydrogels 1:4, 1:3 and 5:3 respectively which indicate the formation of C-O-C bond.X-Ray Diffractometer (XRD) results showed that all starch-based hydrogels were amorphous. Differential Scanning Calorimeter (DSC) gave information that all the blending materials for hydrogel synthesis were of good miscibility and the hydrogel 1:4 was found to have the highest glass transition temperature. From the TGA/DTG thermogram, hydrogel 5:3 was reported to be more stable to heat as compared to other hydrogels. The results from Tensile test using Universal Testing Machine (UTM) have discovered that hydrogels based on the 


\section{Lim et al: PENYEDIAAN DAN PENCIRIAN HIDROGEL BERASASKAN KANJI/AKRILAMIDA DARIPADA UBI Stemona curtisii}

starch of Stemona curtisii possess a potential to be applied as wound dressing. In this test, hydrogel with the lowest starch content, 1:4 showed the highest Young's elastic modulus value.

Keywords: Stemona curtisii, hydrogel, free radical polymerization, microwave

\section{Pengenalan}

Kajian tentang hidrogel telah mendapat perhatian semenjak 50 tahun yang lalu kerana sifatnya yang unik yang membolehkan ia digunakan di dalam pelbagai aplikasi. Selain itu, hidrogel juga mempunyai tahap fleksibiliti yang hampir sama dengan tisu tabii kerana kandungan airnya yang tinggi. Keupayaan hidrogel untuk menyerap air bergantung kepada kumpulan berfungsi hidrofilik yang terdapat pada tulang belakang polimer manakala ketahanannya terhadap pemelarutan berpunca daripada kewujudan taut-silang antara rantai rangkaian [1].

Pada awalnya, hidrogel disintesis secara kimia sama ada melibatkan proses satu langkah atau proses pelbagai langkah. Proses satu langkah yang sering digunakan seperti pempolimeran dan taut-silang selari yang dihubungkan oleh beberapa monomer. Proses pelbagai langkah pula melibatkan sintesis molekul polimer yang mempunyai kumpulan reaktif. Hidrogel boleh direka bentuk dan disintesis dengan kawalan berskala terhadap struktur hidrogel seperti ketumpatan pertautan-silang, ciri biodegradasi, kekuatan mekanikal, tindak balas kimia dan biologi hidrogel terhadap rangsangan [2]. Hidrogel kanji-akrilamida merupakan sejenis hidrogel yang peka terhadap suhu dan $\mathrm{pH}$. Kepekaan hidrogel ini akan menentukan nisbah pengembangannya berdasarkan nilai $\mathrm{pH}$ apabila direndam dalam larutan penimbal. Secara tabiinya, hidrogel yang peka $\mathrm{pH}$ membengkak di dalam air pada $\mathrm{pH}$ tertentu. Hidrogel kanji-akrilamida boleh digunakan sebagai penyerap untuk kegunaan sisa buangan seperti pewarna metilena biru [3].

Para saintis telah mengkaji pempolimeran hidrogel berasaskan kanji dengan menggunakan gelombang mikro. Hasil kajian mereka menunjukkan terdapat tiga keadaan tindak balas akan berlaku dengan penggunaan gelombang mikro: pertama, semua kandungan tindak balas dalam larutan yang homogen adalah larut tanpa ada pemisahan fasa; kedua, bahan tindak balas sama ada polisakarida atau monomer yang tidak larut akan berada dalam larutan tindak balas sebagai ampaian; ketiga, apabila polisakarida dan pemula meresap pada penyokong pepejal tabii, mereka akan wujud sebagai fasa pepejal. Kajian awal turut menunjukkan penggunaan gelombang mikro dapat meningkatkan pembentukan kopolimer dan memberikan produk yang tinggi dalam masa yang singkat berbanding cara pemanasan langsung [4]. Secara umumnya, sinaran gelombang mikro merupakan satu cara pemanasan yang amat menarik. Gelombang ini boleh memanaskan bahan tindak balas terpilih secara langsung dan mempunyai pertukaran haba yang sederhana. Selain itu, kelebihan cara gelombang mikro yang paling ketara sekali adalah tindak balas pempolimeran menggunakan cara ini boleh dilakukan tanpa pemula atau kepekatan pemula yang sangat rendah. Tambahan pula, hidrogel yang dihasilkan melalui cara ini adalah bersifat lebih poros berbanding hidrogel daripada cara konvensional [5].

Ubi Kemili atau nama saintifiknya, Stemona curtisii (Stemonaceae) adalah sejenis ubi yang menjadi makanan ruji bagi penduduk di kawasan pantai timur Semenanjung Malaysia. Ubi ini juga dikenali sebagai sejenis herba saka berumpun yang ditanam sebagai tanaman semusim dengan pokoknya hanya boleh mencapai $60-90 \mathrm{~cm}$ sahaja. Oleh itu, kebanyakan hasil ubinya hanya bersaiz lebih kurang $2-4 \mathrm{~cm}$ panjang dan $0.5-2.0 \mathrm{~cm}$ lebar. Sejak dahulu, Ubi Kemili telah dikenali sebagai Galak Tua, Pokok Seratus atau Pecah Kelambu di kalangan masyarakat Melayu dan 'Bai-bu' dalam masyarakat Cina [6]. Kajian awal telah menunjukkan bahawa ubi spesies Stemona curtisii telah digunakan secara meluas dalam perubatan tradisional di China, Jepun dan Thailand untuk merawat penyakit pernafasan, batuk dan anti-kanser.Selain itu, kajian farmakologi telah menunjukkan bahawa ekstrak daripada spesies ini dapat menghalang pertumbuhan pelbagai jenis bakteria dan kulat di mana mereka telah digunakan sebagai racun serangga [7].

\section{Pengekstrakan kanji daripada Ubi Stemona curtisii}

\section{Bahan dan Kaedah}

Rajah 1 menunjukkan ubi Stemona curtisii yang digunakan dalam penyelidikan ini diperolehi dari Terengganu dan Kelantan, Proses pengekstrakan kanji dimulakan dengan proses basuhan ubi bagi menyingkirkan sebarang kotoran. Ubi dicuci dengan air yang mengalir dan kulitnya dibuang secara menggosok dengan tangan di bawah aliran air. 
Langkah ini perlu diberi perhatian kerana ubi ini mudah teroksida. Oleh itu, ubi harus direndam dalam air suling sebaik sahaja dibuang kulitnya. Ubi dipotong kecil dan dikisar dengan menggunakan pengisar elektronik. Hampas ubi ditapis dengan menggunakan penapis kopi yang diperbuat daripada kain. Proses ini diulang beberapa kali bagi mendapatkan kandungan kanji yang tertinggi. Hasil tapisan dibiarkan selama lima jam untuk membenarkan kanji mendak ke dasar bikar. Kanji yang diperolehi dibasuh dengan menggunakan metanol dan dicuci sebanyak tiga kali lagi dengan air suling bagi menyingkirkan baki metanol yang terdapat pada kanji. Seterusnya kanji dikeringkan secara pengeringan sejuk beku dan dikisar menjadi serbuk.
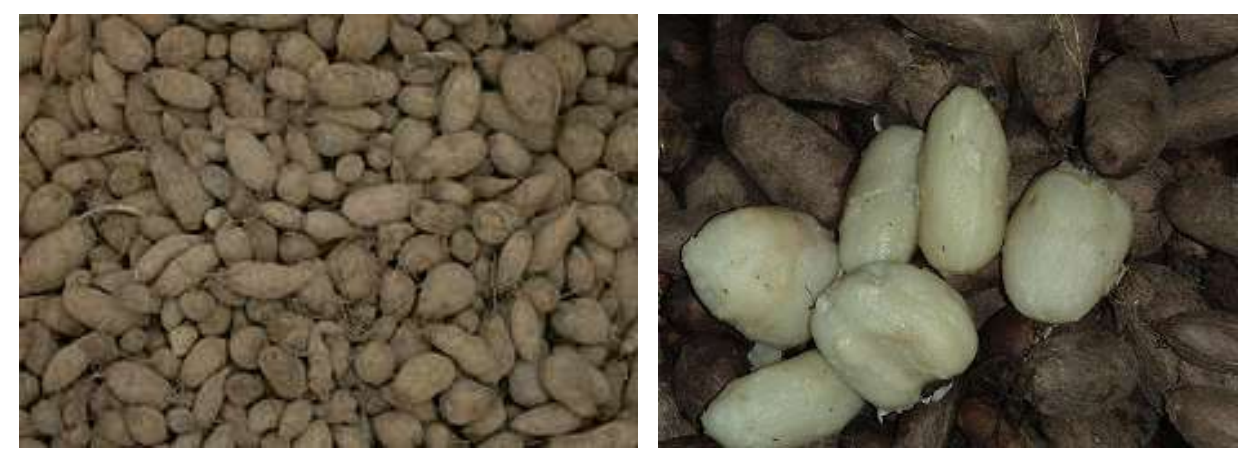

Rajah 1. (a) ubi kemili (Stemona curtisii) dan (b) isi ubi kemili yang bewarna putih susu [7]

\section{Sintesis hidrogel berasaskan kanji daripada Ubi Stemona curtisii}

Untuk menghasilkan hidrogel mengikut kaedah yang dilaporkan oleh Pandey [8], sebanyak 2 g kanji ubi Stemona curtisii dilarutkan dengan menggunakan $15 \mathrm{~mL}$ larutan natrium hidroksida berkepekatan $1 \mathrm{M}$. Campuran ini dikacau berterusan sehingga kedua-dua fasa menjadi homogen dan larutan jernih berwarna kuning-keperangan terhasil. Kemudiaan, $4 \mathrm{~g}$ akrilamida dan $0.05 \mathrm{~g}$ kalium persulfat serta $0.2 \mathrm{~g} \mathrm{~N}, N^{\prime}$-metilenabisakrilamida $(5 \%$ daripada berat akrilamida) ditimbang dan dimasukkan ke dalam larutan kanji. Akrilamida dilarutkan terlebih dahulu dengan menggunakan $5 \mathrm{~mL}$ air suling manakala kalium persulfat dan $N, N^{\prime}$-metilenabisakrilamida masing-masing dilarutkan dengan $2 \mathrm{~mL}$ air suling. Kesemua campuran dikacau dengan menggunakan pengacau bermagnet pada kelajuan $500 \mathrm{rpm}$ selama 3 minit. Apabila larutan menjadi sedikit likat, ia dituang ke dalam piring petri kaca dan didedahkan kepada gelombang mikro berkuasa tetap $100 \mathrm{~W}$ selama 5 minit. Hidrogel yang dihasilkan dibiarkan kering semalaman di dalam kebuk wasap. Proses basuhan dilakukan bagi menyingkirkan bahan - bahan kimia yang tidak bertindak balas. Hidrogel kering direndam selama 2 jam di dalam air suling dan kemudiannya dikeringkan di dalam ketuhar pada suhu $40{ }^{\circ} \mathrm{C}$ selama 24 jam. Jadual 1 menunjukkan komposis berbeza bahan - bahan yang digunakan untuk mensintesis hidrogel.

Jadual 1. Komposisi kanji, AAm, KPS dan MBA yang berbeza di dalam penghasilan hidrogel

\begin{tabular}{ccc}
\hline $\begin{array}{c}\text { Nisbah kanji : akrilamida } \\
(\mathbf{A A m})(\mathbf{g} / \mathbf{g})\end{array}$ & $\begin{array}{c}\text { Pemula } \\
\text { (Kalium Persulfat, KPS) } / \mathbf{g}\end{array}$ & $\begin{array}{c}\text { Agen taut silang } \\
\left(\boldsymbol{N}, \boldsymbol{N}{ }^{\prime} \text {-metilenabisakrilamida,MBA }\right) / \mathbf{g}\end{array}$ \\
\hline $0: 3$ & 0.05 & 0.15 \\
$1: 4$ & 0.05 & 0.20 \\
$1: 3$ & 0.05 & 0.15 \\
$5: 3$ & 0.05 & 0.15 \\
\hline
\end{tabular}




\section{Ujian Pembengkakan Hidrogel}

Dalam kajian ini, ujian pembengkakan hidrogel dilakukan dengan merendam hidrogel ke dalam air suling pada suhu bilik dan beratnya ditimbang setiap 10 minit selama 2 jam. Peratus pembengkakan dikira dengan menggunakan persamaan yang telah dilaporkan oleh Gulrez seperti persamaan berikut [9];

$$
\text { Pembengkakan }(\%)=\frac{W_{a}-W_{d}}{W_{d}} \times 100
$$

di mana, $\mathrm{W}_{\mathrm{s}}$ adalah jisim hidrogel yang membengkak pada masa $\mathrm{t}$ (minit) dan $\mathrm{W}_{\mathrm{d}}$ adalah jisim asal hidrogel.

\section{Mikroskop Pengimbas Elektron (SEM)}

Mikroskop Pengimbas Elektron (SEM) digunakan untuk menganalisis sifat morfologi permukaan hidrogel, keporosan hidrogel dan saiz keporosannya. Sebelum analisis dijalankan, sampel hidrogel dikeringkan terlebih dahulu dengan menggunakan pengering sejuk-beku. Sampel hidrogel kering diletakkan di atas stub aluminium dan disalut dengan emas menggunakan mesin penyalut (SC500, BioRad, UK). Imej morfologi hidrogel dicerap dengan menggunakan mikroskop pengimbas elektron (LEO $1450 \mathrm{VP}$, Germany)

\section{Spektrometer Inframerah Transformasi Fourier-Jumlah Pantulan Teratenuat (ATR-FTIR)}

Analisis menggunakan Spektroskopi Infra Merah adalah bertujuan untuk menentukan proses cangkukan telah berlaku di antara kanji dengan akrilamida. Spektrum Infra Merah direkodkan dengan menggunakan teknik spektroskopi Infra Merah (FTIR/NIR) model: spectrum 400 FT-NIR and spotlight 400 imaging system, Perkin Elmer USA. Sampel hidrogel dikeringkan terlebih dahulu dan spektrum dirakam pada nombor gelombang 400 -

$4000 \mathrm{~cm}^{-1}$. Jenis kristal yang digunakan dalam ATR adalah berlian.

\section{Difraktometer Pembelauan Sinar-X (XRD)}

Difraktometer Pembelauan Sinar-X (XRD) telah digunakan secara meluas dalam penentuan penghabluran pada granul kanji daripada ubi dan hidrogel $[11,12]$. Hidrogel yang disintesis dalam kajian ini dijadikan serbuk dan diuji dengan menggunakan instrumen XRD berjenama Bruker (Siemen) D-5000 pada sudut $2 \theta\left(5^{\circ}-80^{\circ}\right)$.

\section{Kalorimeter Pengimbas Kebedaan (DSC)}

DSC merupakan suatu teknik untuk merakam tenaga yang diperlukan untuk mendapatkan perbezaan suhu sifar di antara sampel dan bahan rujukan terhadap masa atau suhu apabila kedua-duanya didedahkan kepada persekitaran yang dipanaskan atau disejukkan pada kadar terkawal. Dengan memerhatikan perbezaan dalam aliran haba antara sampel dan bahan rujukan, jumlah haba yang diserap atau dibebaskan semasa peralihan itu dapat ditentukan (perubahan entalpi). Alat ini hanya boleh mengesan perbezaan suhu sampel di antara julat suhu $\left(-70{ }^{\circ} \mathrm{C}\right.$ hingga 700 $\left.{ }^{\circ} \mathrm{C}\right)$ dengan bantuan gas nitrogen atau oksigen sebagai gas pembawa. Dalam kajian ini, DSC berjenama Mettler Toledo/822 e digunakan untuk menentukan suhu peralihan kaca $\left(\mathrm{T}_{\mathrm{g}}\right)$ dan kebolehcampuran setiap komponen dalam sampel.

\footnotetext{
Analisis Termagravimetri (TGA)

TGA adalah satu kaedah yang digunakan untuk menentukan perubahan sifat-sifat fizikal dan kimia bahan polimer terhadap suhu. Biasanya, pemanasan yang berterusan dikenakan ke atas sampel untuk mengetahui kehilangan berat bahan polimer. Dalam kajian ini, TGA yang berjenama TA-60WS, Shidmazu Corporation (Kyoto, Japan) digunakan untuk mengetahui kestabilan hidrogel terhadap haba. Sampel hidrogel dikisar menjadi halus lalu pemanasan dilakukan pada julat suhu $0-600{ }^{\circ} \mathrm{C}$ dengan kadar pemanasan $20{ }^{\circ} \mathrm{C} /$ minit. Pada nilai suhu yang tertentu, hidrogel yang stabil akan menunjukkan perubahan jisim yang ketara di mana pengurangan jisim dapat dilihat pada cerun termogram pada nilai suhu itu [13].
}

\section{Ujian regangan hidrogel}

Ujian regangan hidrogel ini dilakukan dengan menggunakan Mesin Ujian Universal (Universal Testing Machine, $U T M$ ) berjenama Instron/5566. Mesin ujian regangan universal adalah alat yang digunakan untuk mengukur kekuatan regangan, mampatan dan kekuatan ricih pada bahan. Sebelum ujian regangan dilakukan, sampel dipotong mengikut bentuk 'dumbell' berdasarkan piawai ASTM (D 638-02a). Ketebalan sampel diukur terlebih dahulu 
dengan menggunakan kaliper. Kemudian, sampel diapit pada Mesin Ujian Universal lalu duji pada kelajuan 3 mili meter/minit.

\section{Penghasilan hidrogel}

\section{Keputusan dan Perbincangan}

Rajah 2 menunjukkan hidrogel yang berjaya disintesis. Dalam penyelidikan ini, hidrogel berasaskan kanji daripada Ubi Stemona curtisii dihasilkan melalui aruhan gelombang mikro dengan menggunakan kalium persulfat, $\mathrm{K}_{2} \mathrm{~S}_{2} \mathrm{O}_{8}$ sebagai pemula radikal, akrilamida (AAm) sebagai monomer dan $N, N^{\prime}$-metilenabisakrilamida (MBA) sebagai agen taut-silang telah berjaya dihasilkan.
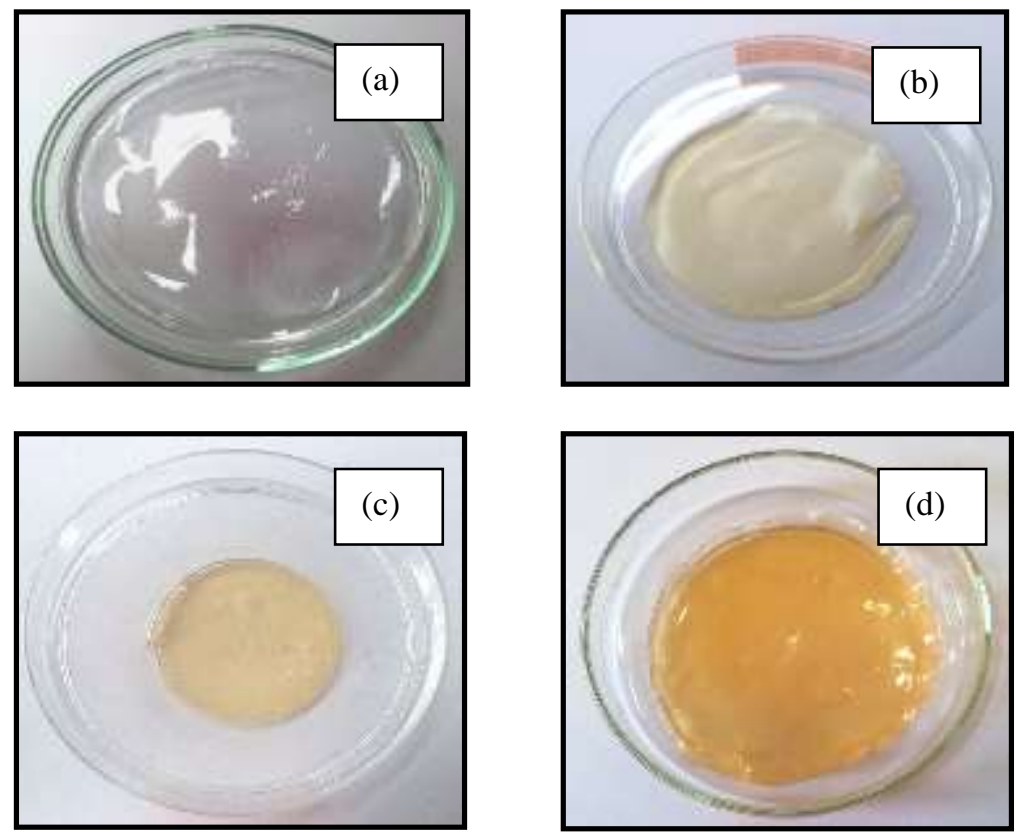

Rajah 2. (a) Hidrogel akrilamida (b) hidrogel dengan nisbah 1:4 (c) hidrogel dengan nisbah 1:3 dan (d) hidrogel dengan nisbah 5:3

Pemerhatian yang teliti terhadap hidrogel yang dihasilkan dari aspek fizikal seperti tahap kekenyalan, tekstur, permukaan dan warna seperti disenaraikan dalam Jadual 2. Cadangan tindak balas adalah seperti yang ditunjukkan dalam Rajah 3.

Jadual 2. Pemerhatian yang teliti terhadap hidrogel yang dihasilkan dari aspek fizikal seperti tahap kekenyalan, tekstur, permukaan dan warna.

\begin{tabular}{ll}
\hline Hidrogel & \multicolumn{1}{c}{ Pemerhatian } \\
\hline Akrilamida & $\begin{array}{l}\text { Berwarna puth lutsinar dengan permukaan yang sangat licin, mempunyai tekstur yang } \\
\text { kurang lembut dan tidak kenyal. } \\
\text { Berwarna kekuningan dengan permukaan yang licin, mempunyai tekstur yang lembut } \\
\text { dan sangat kenyal. }\end{array}$ \\
Nisbah 1:4 & $\begin{array}{l}\text { Berwarna kuning pudar dengan permukaan yang licin, mempunyai tekstur yang } \\
\text { lembut dan kenyal. }\end{array}$ \\
Nisbah 5:3 & $\begin{array}{l}\text { Berwarna kuning gelap dengan permukaan yang kurang licin, mempunyai tekstur yang } \\
\text { lembut dan kurang kenyal. }\end{array}$ \\
\hline
\end{tabular}


Lim et al: PENYEDIAAN DAN PENCIRIAN HIDROGEL BERASASKAN KANJI/AKRILAMIDA

Permulaan rantai

$$
\mathrm{S}_{2} \mathrm{O}_{8}{ }^{-} \longrightarrow 2 \mathrm{SO}_{4}^{-}
$$

$$
\mathrm{Kanji}-\mathrm{OH}+\mathrm{S}_{2} \mathrm{O}_{8}{ }^{2-} \longrightarrow \mathrm{Kanji}-\mathrm{O}^{-}+\mathrm{HSO}_{4}^{-}+\mathrm{SO}_{4}^{-} \text {. }
$$

Perambatan rantai

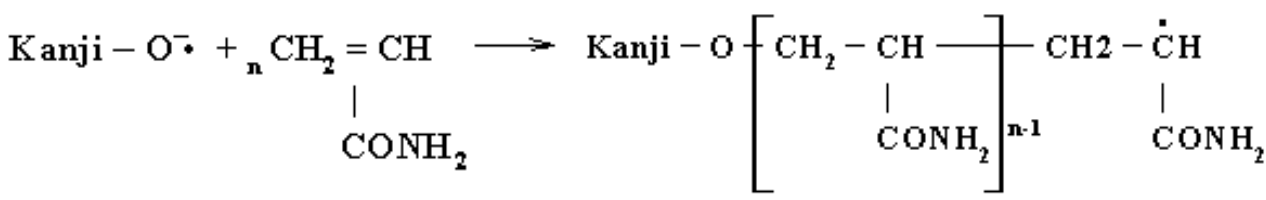

$$
\begin{aligned}
& \underset{\mathrm{SO}_{4}^{-}+{ }_{\mathrm{n}} \mathrm{CH}_{2}=\mathrm{CH}}{\mathrm{CONH}_{2}} \longrightarrow \mathrm{SO}_{4}^{-}-\mathrm{O}\left[\begin{array}{cc}
\mathrm{CH}_{2}-\mathrm{CH} \\
\mid \\
\mathrm{CONH}_{2}
\end{array}\right] \begin{array}{cc}
\mathrm{CH} 2-\dot{\mathrm{CH}} \\
\mathrm{CONH}_{2}
\end{array}
\end{aligned}
$$

Penamatan rantai

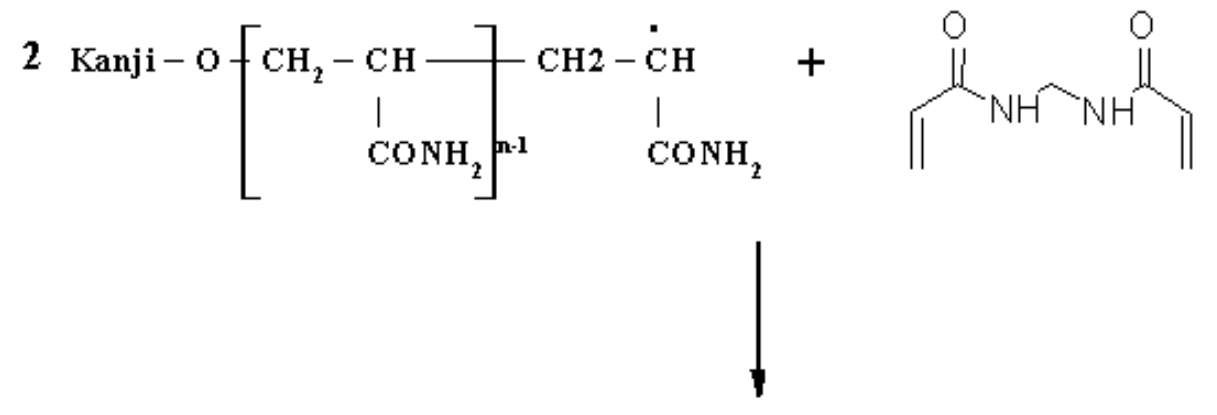

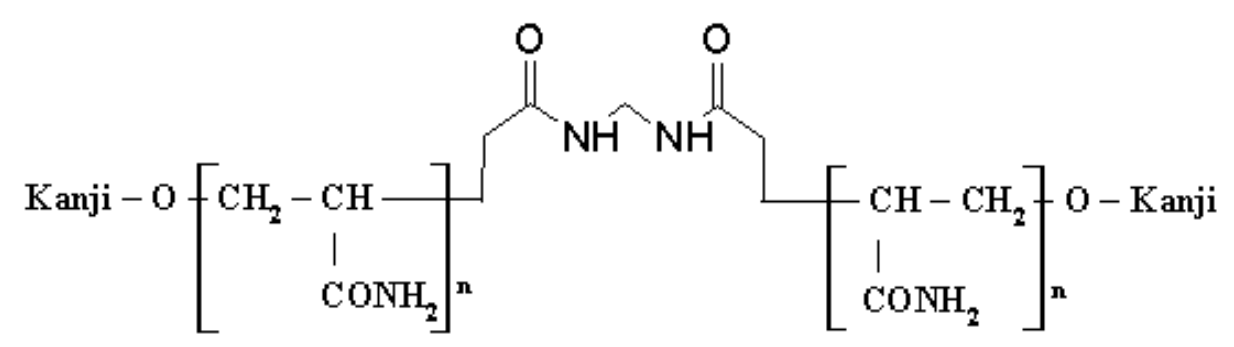

Rajah 3. Cadangan tindak balas penghasilan hidrogel

\section{Mikroskopi Pengimbas Elektron (SEM)}

Dalam kajian ini, 4 jenis sampel hidrogel dengan nisbah yang berbeza yang telah dikeringkan secara pengeringan sejuk-beku telah dianalisis menggunakan SEM. Pengimbasan semua sampel telah ditetapkan pada 1,000 kali gandaan pembesaran dan mikrograf yang diambil seperti ditunjukkan dalam Rajah 4. 

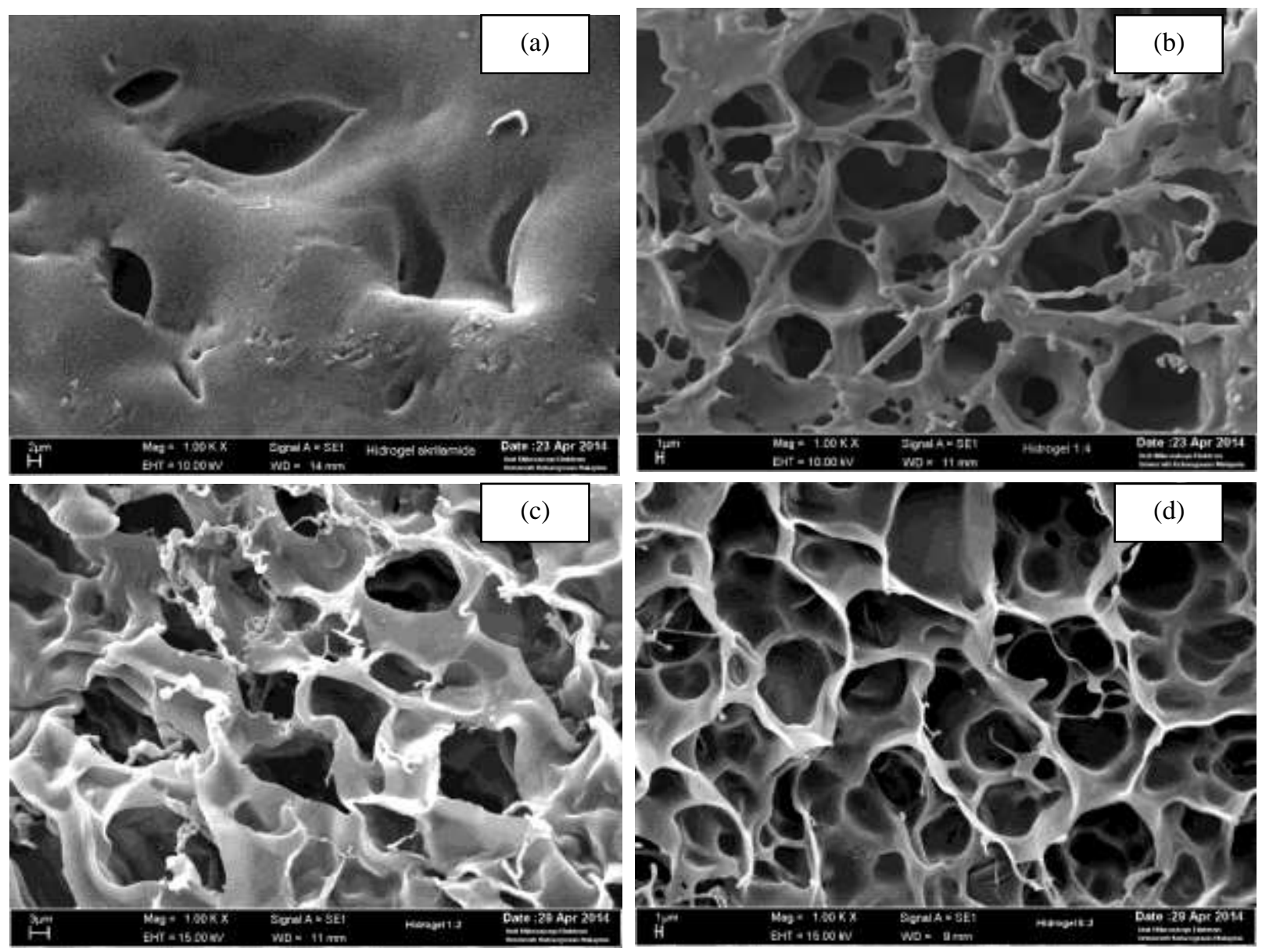

Rajah 4. Mikrograf bagi hidrogel dengan nisbah (a) 0:3, (b) 1:4, (c) 1:3 dan (d) 5:3 pada kuasa pembesaran 1000x

Perbandingan di antara mikrograf bagi sampel hidrogel (a), (b), (d) dan (d) jelas menunjukkan bahawa hidrogel 0:3 (a) mempunyai permukaan yang licin dan tidak poros. Ini membuktikan bahawa penambahan kanji ke dalam formulasi hidrogel dapat meningkatkan keporosan jaringan pada hidrogel [12].

Hidrogel 5: 3 (d) dengan kandungan kanji yang paling tinggi mempunyai banyak liang yang bersaiz kecil (13 -19 $\mu \mathrm{m})$. Fenomena ini berlaku kerana penambahan kanji mengisi ruang antara rangkaian dan memadatkan lagi rangkaian taut-silang dalam hidrogel [13]. Dalam kata lain, darjah taut-silang yang tinggi dan rangkaian hidrogel yang tumpat akan mempunyai saiz poros yang kecil dan menghadkan ruang di dalam jaringan hidrogel. Berdasarkan mikrograf (c) hidrogel 1:3 mempunyai saiz liang yang lebih besar berbanding liang (d) hidrogel 1:4. Julat saiz bagi hidrogel 1:4 dan hidrogel 1: 3 adalah masing-masing di antara $11-22 \mu \mathrm{m}$ dan $10-26 \mu \mathrm{m}$.

\section{Ujian pengembangan hidrogel}

Berdasarkan kepada keputusan ujian pembengkakan yang ditunjukkan pada Rajah 5, hidrogel 1:3 mempunyai peratus pembengkakan paling tinggi iaitu $3881 \%$ diikuti dengan hidrogel 1:4 sebanyak $2373 \%$ dan seterusnya hidrogel 5:3 yang mencatatkan peratus pembengkakan paling rendah iaitu $1285 \%$. 
Lim et al: PENYEDIAAN DAN PENCIRIAN HIDROGEL BERASASKAN KANJI/AKRILAMIDA

DARIPADA UBI Stemona curtisii

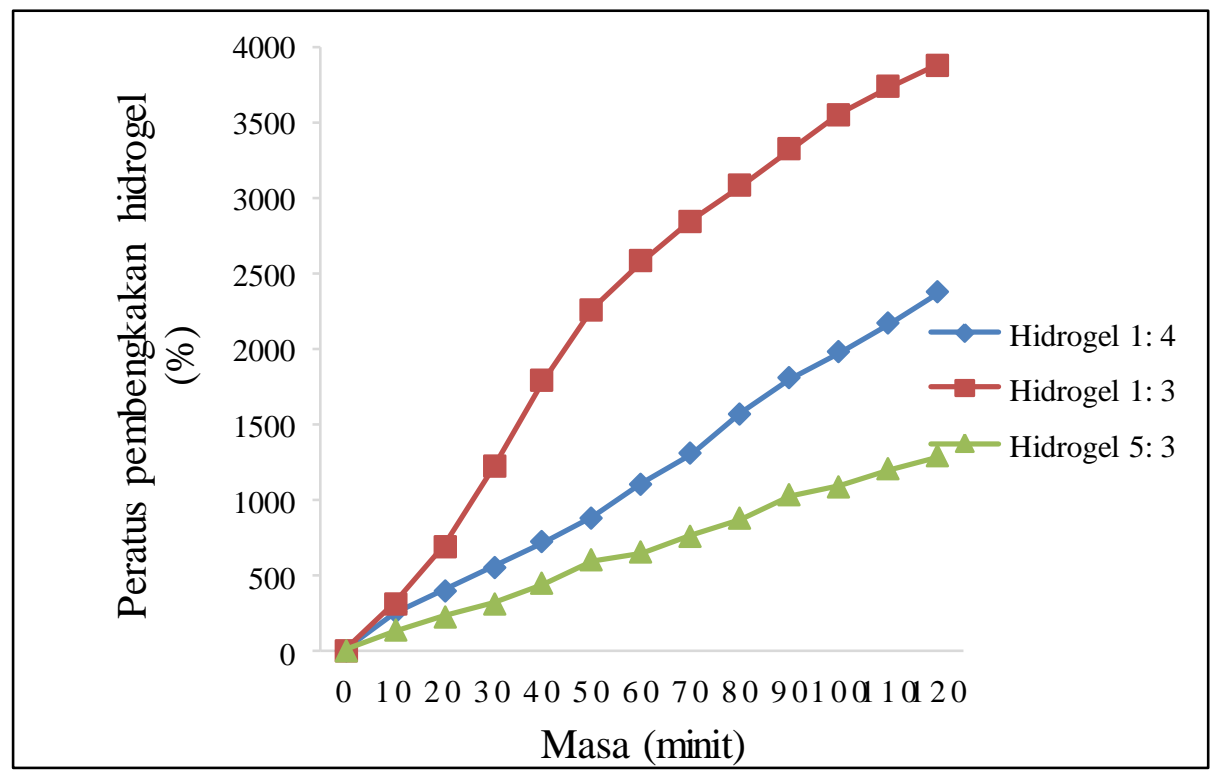

Rajah 5. Graf peratus nisbah pengembangan hidrogel (\%) bagi hidrogel 1:4, 1:3 dan 5:3 selama 2 jam

Hidrogel dengan kandungan kanji yang banyak akan meningkatkan sifat kebolehbasahan, sifat hidrofilik dan darjah pembengkakan [14]. Namun, darjah pembengkakan hidrogel bukan sahaja bergantung pada keadaan hidrogel dan media pembengkakan tetapi ia juga amat bergantung pada ketumpatan taut-silang hidrogel dan kepekatan bahan campur adun seperti kepekatan agen taut-silang dan kepekatan monomer [15].

Dapat diperhatikan pada Rajah 5, hidrogel dengan kandungan kanji yang paling tinggi, 5: 3 mempunyai peratus pembengkakan yang paling rendah. Kandungan kanji yang tinggi dalam hidrogel mengakibatkan rangkaian hidrogel menjadi semakin tumpat. Ini menghadkan ruang di dalam jaringan hidrogel untuk mengembang [13]. Ruang yang terhadap ini secara langsung telah menghalang monomer AAm ataupun kanji untuk mengikat molekul air melalui ikatan hidrogen [15].

Hidrogel 1:4 pula mempunyai nisbah pembengkakan yang lebih rendah berbanding hidrogel 1:3. Hal ini berkaitan rapat dengan jumlah kepekatan komposisi campur-adun. Membandingkan hidrogel 1:3 dan 1:4, hidrogel 1:4 mempunyai kepekatan bahan campur-adun (kepekatanagen taut-silang, MBA dan monomer, AAm) yang lebih tinggi. Secara umumnya, agen taut-silang akan berada di antara rantai monomer untuk mentaut-silangkan rantai rantai monomer tersebut. Maka, bilangan kumpulan hidrofilik yang tersedia untuk membentuk ikatan hidrogen dengan molekul air telah berkurang dan ini menyebabkan pembengkakan hidrogel 1:4 menjadi lebih rendah [16]. Selain itu, kepekatan monomer (AAm) yang lebih tinggi dalam hidrogel 1:4 memadatkan rangkaian polimer hidrogel dan air menjadi lebih sukar untuk meresap ke dalamnya [16]. Oleh itu, hidrogel 1:3 dengan jumlah kepekatan komposisi campur-adunyang lebih rendah mempunyai rangkaian yang tidak begitu padat. Rangkaian dengan ruang antaranya yang besar memudahkan pengikatan dengan molekul air berlaku dan peresapan air ke dalam rangkaian polimernya juga lebih mudah lalu nisbah pengembangan meningkat.

\section{Analisis Spektrometer Inframerah Transformasi Fourier-Jumlah Pantulan Teratenuat (ATR-FTIR)}

Rajah 6 menunjukkan spektrum ATR-FTIR bagi hidrogel yang disintesis dengan menggunakan nisbah kanji terhadap akrilamida yang berbeza. Puncak di antara $3400-3200 \mathrm{~cm}^{-1}$ terdapat pada ketiga - tiga spektrum yang mewakili kumpulan hidroksi pada kanji. Pempolimeran taut silang dikenal pasti telah berlaku berdasarkan kepada pembentukan ikatan C-O-C yang ditunjukkan pada frekuensi $1150-1100 \mathrm{~cm}^{-1}$ [17]. Puncak pada julat frekuensi 
$1000-800 \mathrm{~cm}^{-1}$ juga telah hilang. Ini menandakan bahawa tindak balas pempolimeran antara kumpulan vinil pada monomer telah berlaku. [18].

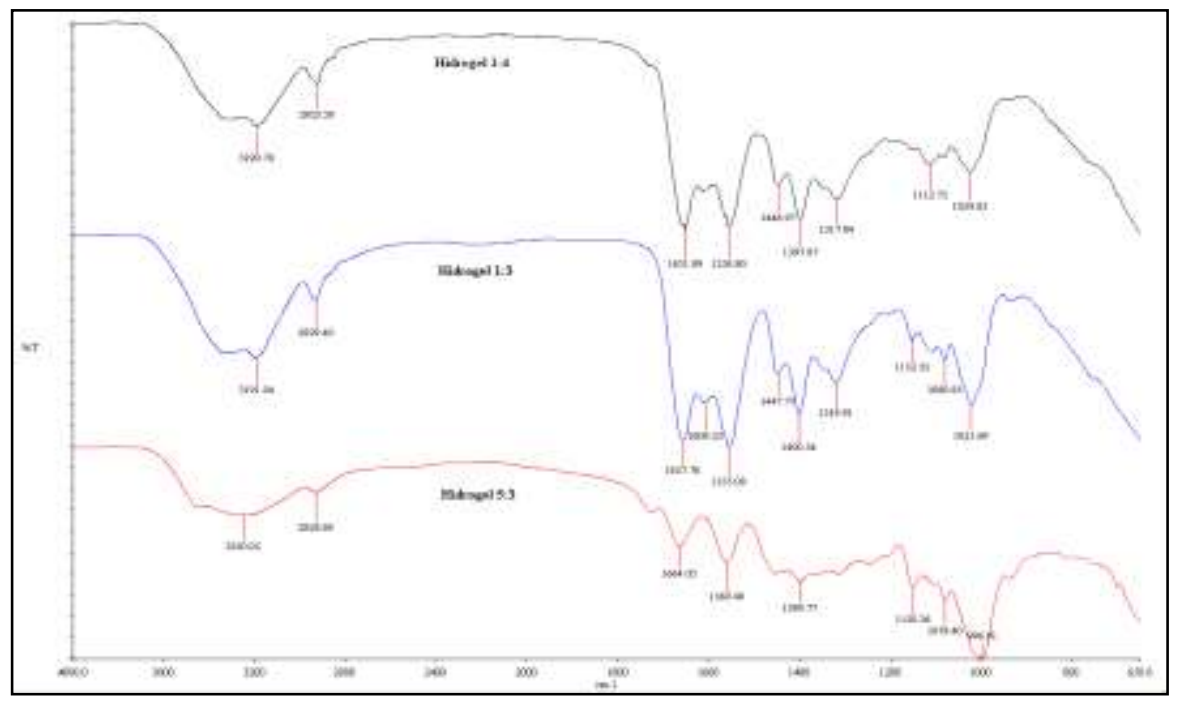

Rajah 6. Perbandingan spektrum inframerah bagi hidrogel 1:4, hidrogel 1:3 dan hidrogel 5:3

\section{Difraktometri Sinar-X (XRD)}

Rajah 7 di bawah menunjukkan difraktogram pembelauan sinar-X bagi sampel kanji Ubi Stemona curtisii, hidrogel akrilamida dan hidrogel berkanji yang dihasil.

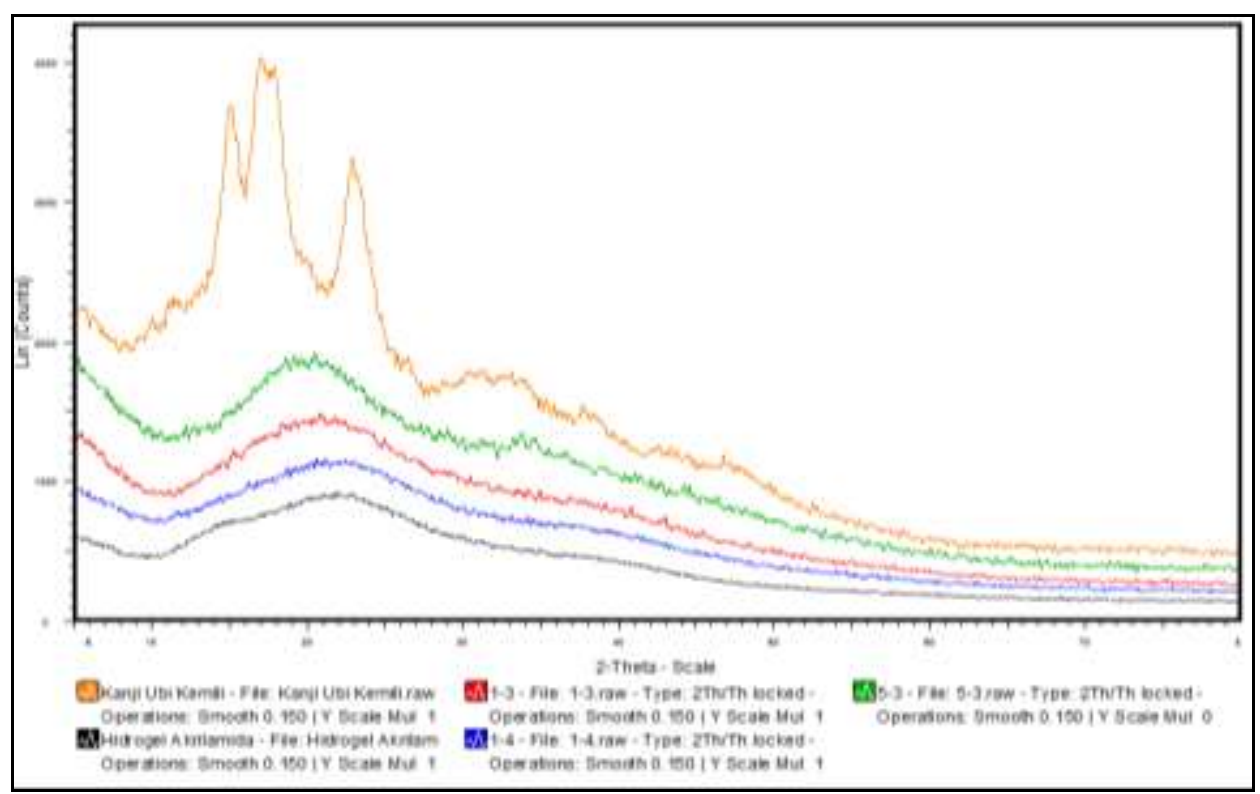

Rajah 7. Difraktogram pembelauan sinar-X sampel kanji, hidrogel akrilamida dan hidrogel berkanji yang dihasil 


\section{Lim et al: PENYEDIAAN DAN PENCIRIAN HIDROGEL BERASASKAN KANJI/AKRILAMIDA DARIPADA UBI Stemona curtisii}

Berdasarkan Rajah 7, kanji Ubi Stemona curtisi menunjukkan sifat penghabluran dengan beberapa puncak keamatan yang tinggi pada belauan dengan skala $2 \theta 15^{\circ}, 17^{\circ}, 18^{\circ}$ dan $23^{\circ}$. Hal ini berlaku kerana disebabkan oleh kehadiran molekul berganda amilopektin di dalam struktur kanji yang boleh menghasilkan satu kawasan kristal jika molekul-molekul tersebut berada pada susunan selari antara satu sama lain manakala molekul amilosa hanya akan membentuk kelompok dan mewujudkan satu rantau tak berhablur yang membawa kepada sifat keamorfusan kanji $[19,20]$.

Berdasarkan kepada difraktogram pada Rajah 7, keempat-empat hidrogel menunjukkan sifat amorfus. Ini menunjukkan morfologi kanji telah berubah setelah proses pempolimeran/taut-silang untuk menghasilkan hidrogel berkanji. Puncak kanji yang tinggi pada belauan berskala $2 \theta 15^{\circ}, 17^{\circ}, 18^{\circ}$ dan $23^{\circ}$ tidak lagi wujud dalam difraktogram hidrogel. Menurut Bhattachary [21], hidrogel bersifat amorfus kerana taut silang dalam polimer hidrogel menghalang rangkaian daripada bersusun padat dalam orientasi berkala, rangkaian tidak dapat menggelongsor antara satu sama lain lalu tidak mempunyai sifat hablur tetapi menjana kekenyalan dalam hidrogel amorfus.

\section{Kalorimeter Pengimbas Kebedaan (DSC)}

Berdasarkan kepada Rajah 8 didapati bahawa setiap termogram sampel hanya terdapat nilai tunggal suhu peralihan kaca. Ini telah jelas menunjukkan bahawa semua bahan campur-adun yang digunakan untuk sintesis hidrogel adalah pada tahap kebolehcampuran yang baik. Menurut Diab [22] sistem polimer hidrogel yang terlarut campur dengan baik menunjukkan suhu peralihan kaca yang tunggal manakala jika suatu sistem itu tidak serasi akan mempunyai beberapa suhu peralihan kaca secara terasing yang mewakili setiap komponen dalam polimer hidrogel.

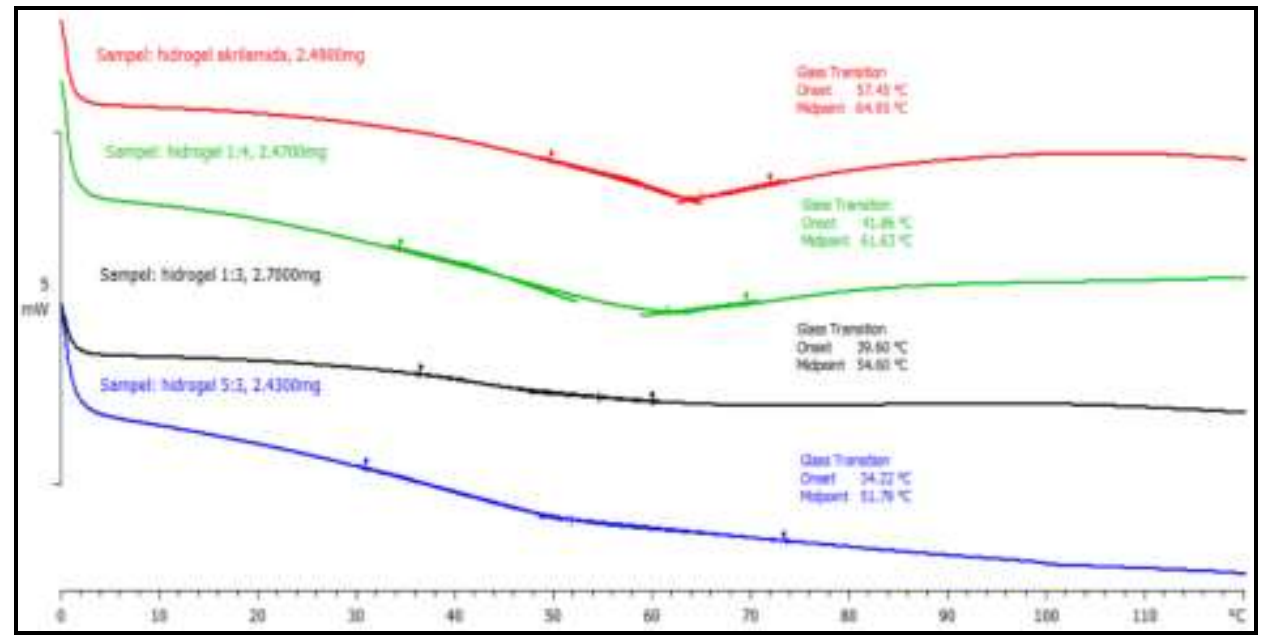

Rajah 8. Gabungan termogram DSC bagi hidrogel 0:3, hidrogel 1:4, hidrogel 1:3 dan hidrogel 5:3.

Jadual 3 menunjukkan suhu peralihan kaca bagi keempat-empat jenis hidrogel yang telah disintesis. Keputusan menunjukkan hidrogel kosong (0:3) mempunyai nilai $\mathrm{T}_{\mathrm{g}}$ yang paling tinggi dan diikuti oleh hidrogel 1:4 (mempunyai kandungan kanji yang paling rendah), 1:3 (mempunyai kandungan kanji yang sederhana) dan 5:3 (mempunyai kandungan kanji yang paling tinggi). Ini telah menunjukkan bahawa kepekatan kandungan kanji mempengaruhi nilai $\mathrm{T}_{\mathrm{g}}$ hidrogel yang dihasil. Semakin banyak kanji yang ditambahkan ke dalam sintesis hidrogel, semakin rendah nilai $T_{g}$ hidrogel itu. Penurunan nilai $T_{g}$ hidrogel ini berlaku disebabkan molekul air cenderung untuk mengikat pada molekul kanji dan menyebabkannya berfungsi sebagai pemplastik, maka hidrogel dengan kandungan kanji yang lebih tinggi akan mengalami penurunan nilai $\mathrm{T}_{\mathrm{g}}$ akibat peningkatan sifat pemplastikan [17]. Hidrogel kosong pula mempunyai nilai $T_{g}$ yang paling tinggi kerana ia tidak mempunyai kanji. Ketidakhadiran kanji menyebabkannya kurang sifat plastik dan mempamerkan nilai $\mathrm{T}_{\mathrm{g}}$ yang lebih tinggi. 
Kajian turut mencatatkan peningkatan penambahan monomer akrilamida dalam sintesis hidrogel meningkatkan nilai $\mathrm{T}_{\mathrm{g}}$ hidrogel. Ini jelas dilihat daripada nilai $\mathrm{T}_{\mathrm{g}}$ hidrogel 1:4 yang dihasil daripada paling banyak monomer adalah paling tinggi iaitu pada $65.0{ }^{\circ} \mathrm{C}$. Peningkatan penambahan monomer (akrilamida) dapat meningkatkan nilai suhu $\mathrm{T}_{g}$ polimer hidrogel kerana ia menguatkan ikatan hidrogen antara rangkaian polimer lalu dapat menstabilkan polimer hidrogel [23]. Keputusan yang sama telah diperolehi oleh Painter [24] di mana mereka turut mencadangkan sifat ini sering dijumpai dalam adunan hidrogel kerana interaksi ikatan hidrogen.

Jadual 3. Suhu peralihan kaca bagi hidrogel yang berbeza komposisi bahan mula

\begin{tabular}{lcc}
\hline Warna Termogram DSC & Sampel & $\begin{array}{c}\text { Suhu peralihan kaca hidrogel } \\
\left({ }^{\circ} \mathbf{C}\right)\end{array}$ \\
\hline Merah & Hidrogel $0: 3$ & 65.0 \\
Hijau & Hidrogel $1: 4$ & 61.6 \\
Hitam & Hidrogel $1: 3$ & 54.6 \\
Biru & Hidrogel $5: 3$ & 51.8 \\
\hline
\end{tabular}

\section{Analisis Termogravimetrik (TGA)}

Dalam kajian ini, analisis TGA dijalankan untuk mengetahui kestabilan/ketahanan hidrogel berasaskan kanji daripada Ubi Stemona curtisii terhadap haba. Data berkaitan dengan nilai peratus kehilangan jisim pada setiap peringkat, jumlah peratus kehilangan jisim dan peratus jisim yang masih ada pada suhu $600{ }^{\circ} \mathrm{C}$ dalam kanji Ubi Stemona curtisii dan setiap hidrogel yang disintesis telah disenaraikan dalam Jadual 4.

Jadual 4. Nilai peratus kehilangan jisim pada setiap peringkat, peratus kehilangan jisim maksima dan peratus jisim baki dalam kanji Ubi Stemona curtisii dan setiap hidrogel yang disintesis.

\begin{tabular}{|c|c|c|c|c|c|}
\hline \multirow[b]{2}{*}{ Sampel } & \multicolumn{3}{|c|}{ Peratus Kehilangan Jisim (\%) } & \multirow{2}{*}{$\begin{array}{c}\text { Peratus } \\
\text { Kehilangan } \\
\text { Jisim } \\
\text { Maksima (\%) } \\
\end{array}$} & \multirow{2}{*}{$\begin{array}{c}\text { Peratus } \\
\text { Jisim } \\
\text { Baki } \\
(\%) \\
\end{array}$} \\
\hline & $\begin{array}{c}\text { Peringkat } \\
\text { pertama } \\
\left(0-250{ }^{\circ} \mathrm{C}\right) \\
\end{array}$ & $\begin{array}{c}\begin{array}{c}\text { Peringkat } \\
\text { kedua } \\
\left(280-450{ }^{\circ} \mathrm{C}\right)\end{array} \\
\end{array}$ & $\begin{array}{c}\begin{array}{c}\text { Peringkat } \\
\text { ketiga }\end{array} \\
\left(450-600{ }^{\circ} \mathrm{C}\right)\end{array}$ & & \\
\hline Kanji & 10 & 76 & - & - & - \\
\hline Hidrogel 0: 3 & 9 & 59 & 11 & 79 & 21 \\
\hline Hidrogel 1: 4 & 7 & 44 & 23 & 74 & 26 \\
\hline Hidrogel 1: 3 & 7 & 47 & 18 & 72 & 28 \\
\hline Hidrogel 5: 3 & 12 & 38 & 19 & 69 & 31 \\
\hline
\end{tabular}

Peringkat pertama kehilangan jisim yang berlaku pada sekitar $0-250{ }^{\circ} \mathrm{C}$ boleh dikaitkan dengan penyejatan air yang terjerap secara fizikal atau kimia dalam semua sampel manakala peringkat penguraian yang lain adalah disebabkan oleh penguraian terma sampel $[13,25]$. Secara keseluruhannya, semua hidrogel dengan kehadiran kanji mengalami peratus kehilangan jisim yang lebih rendah berbanding dengan hidrogel kosong. Hal ini kerana dalam hidrogel berkanji,atom hidrogen daripada kumpulan hidroksi primer dalam molekul kanji telah digantikan oleh monomer semasa perpautan-silang.Taut-silang antara monomer dan molekul kanji Ubi Stemona curtisii menghasilkan ikatan baru dan ikatan inilah yang menyebabkan hidrogel berkanji lebih stabil terhadap haba [17, 26]. 
Daripada keputusan kajian juga boleh dilihat hidrogel yang mempunyai lebih banyak kanji adalah lebih tahan haba dan mengalami peratus kehilangan jisim maksima yang lebih rendah. Hidrogel 5:3 (kandungan kanji paling tinggi) mempunyai jisim sampel yang paling tinggi pada suhu $600{ }^{\circ} \mathrm{C}$ diikuti oleh hidrogel 1:3 (kandungan kanji yang sederhana) dan hidrogel 1:4 (kandungan kanji paling rendah).Peratus jisim baki sampel-sampel tersebut pada suhu $600{ }^{\circ} \mathrm{C}$ adalah masing-masing 31, 28 dan $26 \%$. Kandungan kanji yang tinggi dalam hidrogel 5:3 menyebabkan rangkaiannya menjadi sangat padat dan mempunyai lebih banyak amilopektin (struktur rantai bercabang). Kandungan amilopektin mendorong kepada ketahanan sampel hidrogel terhadap haba kerana penguraiannya memerlukan suhu yang lebih tinggi berbanding rantai linear (amilosa) [17, 27].

Selain itu, tahap kestabilan/ketahanan sesuatu sampel terhadap haba juga berkait rapat dengan tahap penghabluran sampel itu. Peningkatan kandungan kanji dalam suatu sampel meningkatkan tahap penghabluran sampel dan meningkatkan tahap ketahanan sampel tersebut terhadap haba [28]. Oleh itu,semua hidrogel yang mempunyai kanji akan menunjukkan tahap ketahanan terhadap haba yang lebih tinggi berbanding hidrogel kosong [26].

\section{Ujian tegangan hidrogel}

Rajah 9 di bawah menunjukkan graf bar modulus elastik bagi setiap nisbah hydrogel yang telah disintesis. Berdasarkan Rajah 4.9, hidrogel 1:4 yang mempunyai kandungan kanji paling rendah telah menunjukkan nilai modulus elastik yang paling tinggi dan dikuti oleh hidrogel 1:3. Hidrogel 5:3 yang mengandungi berat kanji paling tinggi pula menunjukkan nilai modulus elastik dan tegasan tegangan yang paling rendah. Keputusan kajian menunjukkan tahap kekenyalan hidrogel menurun akibat peningkatan kandungan kanji (bahan asas) yang ditambah dalam sintesis hidrogel. Hal ini kerana penambahan kanji dalam hidrogel akrilamida menyebabkan sampel hidrogel itu menjadi lebih tegar. Hidrogel yang tegar menjejaskan kestabilan proses pemanjangannya kerana hidrogel yang tegar ini tidak akan terus memanjang untuk satu tempoh yang lama tetapi ia mudah putus. Maka, hidrogel yang mudah putus ini tidak bersifat elastik dan akan mempunyai nilai Young's modulus yang rendah [12]. Keputusan yang sama telah dilaporkan oleh [27]

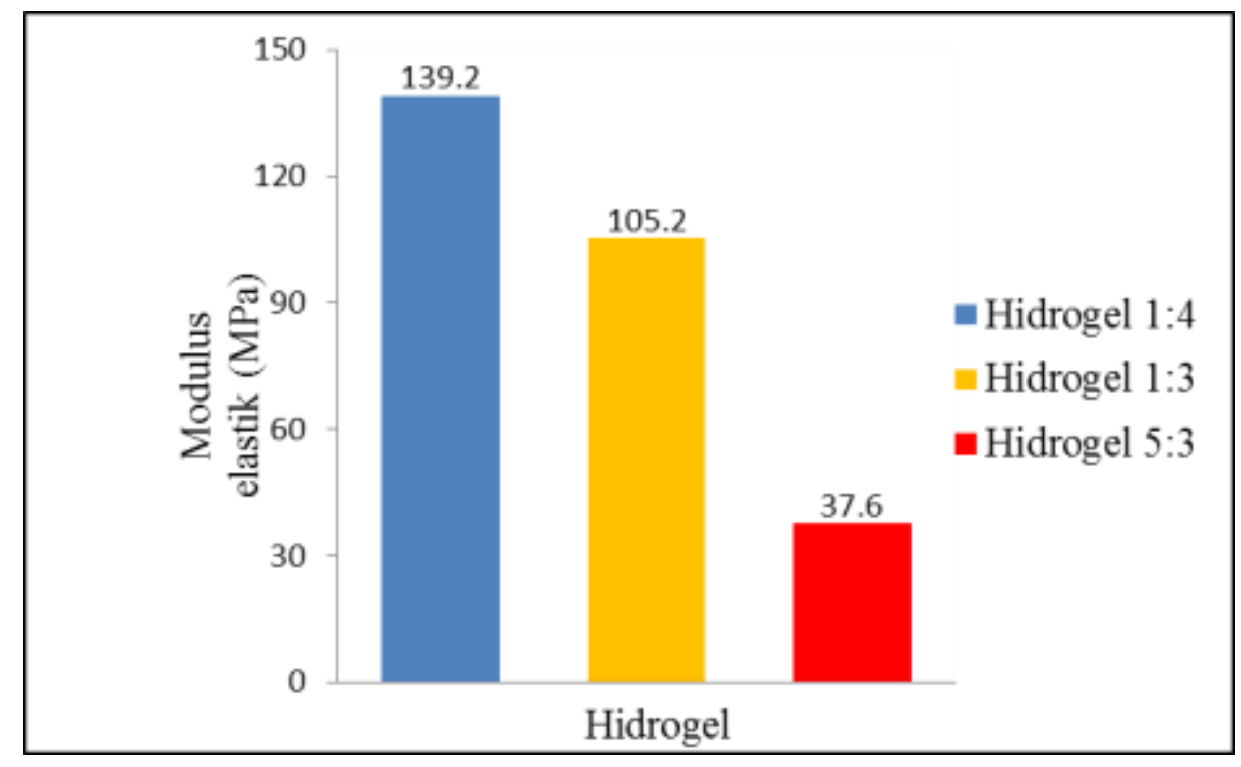

Rajah 9. Graf bar modulus elastik bagi hidrogel dengan nisbah kanji : akrilamida $1: 4,1: 3,5: 3$.

Walau bagaimanapun, hidrogel berasaskan kanji daripada Ubi Stemona curtisii ini mempunyai potensi untuk diaplikasikan sebagai pembalut luka. Menurut laporan Gallagherdan [30] nilai kegagalan tegangan kulit adalah 34 MPa. Semua nilai modulus elastik hidrogel yang dihasilkan dalam kajian ini adalah lebih tinggi daripada nilai 
kegagalan tegangan kulit. Oleh itu, hidrogel yang dihasilkan ini boleh digunakan untuk meliputi luka kerana tahap kekenyalannya yang tinggi boleh menahan tegasan geseran yang dan dapat menyerap tenaga tanpa pecah dan memberi kesan perlindungan terhadap luka [31].

\section{Kesimpulan}

Kajian yang dilakukan ini telah berjaya menghasilkan hidrogel berasaskan-kanji Ubi Stemona curtisii dengan menggunakan gelombang mikro. Penggunaan gelombang mikro membolehkan tindak balas berlaku pada kehadiran kepekatan bahan pemula yang lebih rendah dan lebih menjimatkan masa sintesis. Justeru, penghasilan hidrogel menggunakan kaedah gelombang mikro ini dilihat dapat dikomersilkan terutamanya di dalama bidang biobahan.

\section{Penghargaan}

Penulis ingin mengucapkan setinggi - tinggi penghargaan dan terima kasih kepada kakitangan makmal di Jabatan Kimia, Fakulti Sains dan Teknologi serta Universiti Kebangsaan Malaysia (FRGS/1/2014/ST01/UKM/03/1 dan PRGS/1/2014/TK04/UKM/03/1) di atas sokongan, bantuan dan bimbingan sepanjang tempoh kerja makmal dijalankan.

\section{Rujukan}

1. Hartmann, J. (1990). Absorbent Polymer Technology. The Netherlands: Elsevier Science Publishers B.V.

2. Burkert, S., Schmidt, T., Gohs, U., Dorschner, H. and Arndt, K. F. (2007). Cross-linking of poly(N-vinyl pyrrolidone) films by electron beam irradiation. Radiation Physics and Chemistry 76(8-9): 1324 - 1328.

3. Paulino, A. T., Guilherme, M. R., Reis, A.V., Campese, G. M., Muniz, E. C. and Nozaki, J. (2006). Removal of methylene blue dye from an aqueous media using superabsorbent hydrogel supported on modified polysaccharide. Journal of Colloid and Interface Science 301(1): 55 - 62.

4. Singh, V., Tiwari, A., Pandey, S. and Singh, S. K. (2006). Microwave-accelerated synthesis and characterization of potato starch-g-poly(acrylamide). Starch - Stärke 58(10): 536 - 543.

5. Yang, X. M., Liu, Q., Chen, X. L., Yu, F. and Zhu, Z. Y. (2008). Investigation of PVA/WS-chitosan hydrogels prepared by combined $\gamma$-irradiation and freeze-thawing. Carbohydrate Polymers 73(3): $401-408$.

6. Zainura (2010). Galak tua (Stemona) - Stemona tuberosa. http://wannura.wordpress.com/2010/01/22 /galaktua-stemona-stemona-tuberosa-lour/ [9 November 2013].

7. Zhao, W. M., Qin, G. W., Ye, Y., Xu, R. S. and Le, X. F. (1995). Bibenzyls from Stemona tuberosa. Phytochemistry 38(3): $711-713$.

8. Pandey, M. and Amin, M. C. I. M. (2012). Accelerated preparation of novel bacterial cellulose/acrylamidebased hydrogel by microwave irradiation. International Journal of Polymeric Materials and Polymeric Biomaterials 62(7): $402-405$.

9. Gulrez, S. K. H. and Al-Assaf, S. (2011). Hydrogels: Methods of preparation, characterisation and applications. Dlm. Carpi, P.A. (Ed.). Progress in molecular and environmental bioengineering - from analysis and modeling to technology applications, United Kingdom: InTech Europe: pp 646.

10. Dai, T., Qing, X., Wang, J., Shen, C. and Lu, Y. (2010). Interfacial polymerization to high-quality polyacrylamide/polyaniline composite hydrogels. Composites Science and Technology 70(3): 498 -503.

11. Zobel, H. F., Young, S. N. and Rocca, L.A. (1988). Starch gelatination: An X-ray diffraction study. Cereal Chemistry 65(6): $443-446$.

12. Kenawy, E.-R., Kamoun, E. A., Mohy Eldin, M. S. and El-Meligy, M. A. (2013). Physically crosslinked poly(vinyl alcohol)-hydroxyethyl starch blend hydrogel membranes: Synthesis and characterization for biomedical applications. Arabian Journal of Chemistry 6(2): 1 - 9.

13. Abd El-Mohdy, H. L., Hegazy, E. A., El-Nesr, E. M. and El-Wahab, M. A. (2012). Synthesis, characterization and properties of radiation-induced starch/(EG-co-MAA) hydrogels. Arabian Journal of Chemistry 5: 1 - 9.

14. Li, A., Liu, R. and Wang, A. (2005). Preparation of starch-graft-poly(acrylamide)/attapulgite superabsorbent composite. Journal of Applied Polymer Science 98(3): 1351 - 1357.

15. Seddiki, N. and Aliouche, D. (2013). Synthesis, rheological behavior and swelling properties of copolymer hydrogels based on poly(N-isopropylacrylamide) with hydrophilic monomers. Chemical Society of Ethiopia 27(3): $447-457$.

16. Isik, B. (1998). Swelling behavior of acrylamide-2-hydroxyethyl methacrylate hydrogels. Turkey Journal of Chemistry 24(2): $147-156$. 
Lim et al: PENYEDIAAN DAN PENCIRIAN HIDROGEL BERASASKAN KANJI/AKRILAMIDA DARIPADA UBI Stemona curtisii

17. Amin, M. C. I. M., Ahmad, N., Halib, N. and Ahmad, I. (2012). Synthesis and characterization of thermo- and pH-responsive bacterial cellulose/acrylic acid hydrogels for drug delivery. Carbohydrate Polymers 88(2): 465 473.

18. Zhao, Z., Li, Z., Xia, Q., Xi, H. and Lin, Y. (2008). Fast synthesis of temperature-sensitive PNIPAAm hydrogels by microwave irradiation. European Polymer Journal 44(4): 1217 -1224.

19. Blanche, S. and Sun, X. (2004). Physical characterization of starch extrudates as a function of melting transitions and extrusion conditions. Advances in Polymer Technology 23(4): 277 - 290.

20. Cheetham, N. W. H. and Tao, L. (1998). Solid state NMR studies on the structural and conformational properties of natural maize starches. Carbohydrate Polymers 36(4): 285 - 292.

21. Bhattachary, A., Rawlins, J. W. and Ray, P. (2009). Polymer Grafting and Crosslinking. United States of America: John Wiley \& Sons Inc.

22. Diab, T., Biliaderis, C. G., Gerasopoulos, D. and Sfakiotakis, E. (2001). Physicochemical properties and application of pullulan edible films and coatings in fruit preservation. Journal of the Science of Food and Agriculture 2(81): $988-1000$.

23. Xia, Y. Q., Guo, T. Y., Song, M. D., Zhang, B. H. and Zhang, B. L. (2005). Hemoglobin recognition by imprinting in semi-interpenetrating polymer network hydrogel based on polyacrylamide and chitosan. Biomacromolecules 6(5): 2601 - 2606.

24. Painter, P. C., Graf, J. F. and Coleman, M. M. (1991). Effect of hydrogen bonding on the enthalpy of mixing and the composition dependence of the glass transition temperature in polymer blends. Macromolecules 24(20): $5630-5638$.

25. Bursali, E. A., Coskun, S., Kizil, M. and Yurdakoc, M. (2011). Synthesis, characterization and in vitro antimicrobial activities of boron/starch/polyvinyl alcohol hydrogels. Carbohydrate Polymers 83(3): 1377 1383.

26. Vakili, M. R. and Rahneshin, N. (2013). Synthesis and characterization of novel stimuli-responsive hydrogels based in starch and l-aspartis acid. Carbohydrate Polymers 9(8): $1624-1630$.

27. Liu, X., Wang, Y., Yu, L., Tong, Z., Chen, L., Liu, H. and Li, X. (2013). Thermal degradation and stability of starch under different processing conditions. Starch - Stärke 65(1-2): $48-60$.

28. French, D. (1972). Fine structure of starch and its relationship to the organization or starch granules. Journal of Japanese Society for Starch Science 19(1): 8 - 25.

29. Razzak, M. T., Darwis, D. and Zainuddin, S. (2001). Irradiation of polyvinyl alcohol and polyvinyl pyrrolidone blended hydrogel for wound dressing. Radiation Physics and Chemistry 62(1): $107-113$.

30. Gallagher, A. J., Anniadh, A. N., Bruyere, K., Otténio, M., Xie, H. and Gilchrist, M. D. (2012). Dynamic tensile properties ofhuman skin. International IRCOBI Conference on the Biomechanics of Injury, $\mathrm{pp}$ $494-502$.

31. Kunal, P., Banthia, A. K. and Majumdar, D. K. (2006). Preparation of transparent starch based hydrogel membrane with potential application as wound dressing. Trends in Biomaterials and Artificial Organs 20(1): $59-67$. 